\title{
Biochemical Basis of Prolidase Deficiency \\ Polypeptide and RNA Phenotypes and the Relation to Clinical Phenotypes
}

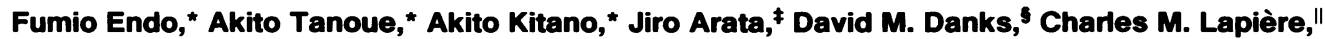 \\ Yoshihiro Sei," Sybe K. Wadman," and Ichiro Matsuda* \\ ${ }^{*}$ Department of Pediatrics, Kumamoto University Medical School, Kumamoto, Japan; ${ }^{\ddagger}$ Department of Dermatology, Okayama \\ University Medical School, Okayama, Japan; ${ }^{\S}$ The Murdoch Institute, Royal Children's Hospital, Victoria, Australia; "Department of \\ Dermatology, University of Liége, Liége, Belgium; 'Department of Dermatology, Kanazawa Medical University, Uchinada, Japan; and \\ **Wilhelmina Children's Hospital, Utrecht, The Netherlands
}

\begin{abstract}
Cultured skin fibroblasts or lymphoblastoid cells from eight patients with clinical symptoms of prolidase deficiency were analyzed in terms of enzyme activity, presence of material crossreacting with specific antibodies, biosynthesis of the polypeptide, and mRNA corresponding to the enzyme. There are at least two enzymes that hydrolyze imidodipeptides in these cells and these two enzymes could be separated by an immunochemical procedure. The specific assay for prolidase showed that the enzyme activity was virtually absent in six cell strains and was markedly reduced in two ( $<3 \%$ of controls). The activities of the labile enzyme that did not immunoprecipitate with the anti-prolidase antibody were decreased in the cells (30-60\% of controls).

Cell strains with residual activities of prolidase had immunological polypeptides crossreacting with a $M_{\mathrm{r}} 56,000$, similar to findings in the normal enzyme. The polypeptide biosynthesis in these cells and the controls was similar. Northern blot analyses revealed the presence of mRNA in the polypeptide-positive cells, yet it was absent in the polypeptide-negative cells. The substrate specificities analyzed in the partially purified enzymes from the polypeptide-positive cell strains differed, presumably due to different mutations. Thus, there seems to be a molecular heterogeneity in prolidase deficiency.

There was no apparent relation between the clinical symptoms and the biochemical phenotypes, except that mental retardation was present in the polypeptide-negative patients. The activities of the labile enzyme may not be a major factor in modifying the clinical symptoms. (J. Clin. Invest. 1990. 85:162-169.) biosynthesis - crossreacting materials $•$ deficiency $\bullet$ mRNA $\bullet$ peptidase $\bullet$ prolidase
\end{abstract}

\section{Introduction}

Prolidase deficiency is an autosomal recessive disorder characterized by mental retardation, various skin lesions, and abnormalities of collagenous tissues (1). Prolidase catalyzes hydroly-

Part of this work was presented at the Annual Meeting of the Japanese Society for Inborn Errors of Metabolism, Tokyo, Japan, October 1988.

Please address reprint requests to Dr. Fumio Endo, Department of Pediatrics, Kumamoto University Medical School, Honjo 1-1-1, Kumamoto 860, Japan.

Received for publication 12 June 1989 and in revised form $28 \mathrm{Au}$ gust 1989.

J. Clin. Invest.

(C) The American Society for Clinical Investigation, Inc.

$0021-9738 / 90 / 01 / 0162 / 08 \$ 2.00$

Volume 85, January 1990, 162-169 sis of di- and tripeptides with carboxy-terminal proline and seems to play an important role in the recycling of proline. As a consequence of the deficiency of prolidase, massive imidopeptiduria and relatively lowered levels of plasma proline are present in the patients (1). The precise mechanisms involved in the development of skin lesions, mental retardation, and other symptoms including splenomegaly, osteoporosis, and frequent infections have not been completely elucidated.

More than 20 cases of prolidase deficiency have been reported, and some of the patients had no clinical symptoms of the disease $(2,3)$. The symptoms do not seem to be related to severities produced by the enzyme defect, as deduced from individual case reports. Clinical symptoms appear gradually; hence, an assessment of the symptoms at the time of the diagnosis or during the relatively short period of the investigations is difficult. The hydrolytic activities toward imidodipeptides in crude extracts of tissues and cells may not solely represent the activity of a single enzyme (4) and activities of prolidase in cases of a deficiency may not reflect residual activities of prolidase itself, which is genetically defective.

We purified human prolidase to apparent homogeneity and prepared anti-prolidase monoclonal and polyclonal antibodies for use in the immunochemical analysis of prolidase deficiency (5). Boright et al. (6) most recently developed a polyclonal antibody directed against prolidase and used it to analyze cells from prolidase-deficient patients. We used the antibodies to identify a cDNA clone corresponding to the human prolidase mRNA (7). Based on the partial amino acid sequence of the purified enzyme and the nucleotide sequence of the cDNA clones, the primary structure of human prolidase has been deduced (8).

We have now examined the biochemical basis of prolidase deficiency using cultured skin fibroblasts or cultured lymphoblastoid cells obtained from subjects from families with prolidase deficiency. The availability of the specific antibodies and the cloned cDNA facilitated a definition of the polypeptide and RNA phenotypes of these patients. The biochemical and clinical phenotypes were compared.

\section{Methods}

Materials. IgG-EP2, EP10, and EP38 mouse MAbs that bind to human prolidase, and IgG-NR, a control mouse MAb directed against an irrelevant antigen, were prepared by the hybridoma technique described elsewhere (5). Human prolidase was then purified from peripheral erythrocytes using an immunoaffinity gel (9). Polyclonal antiserum was developed in rabbits by injecting purified human prolidase. Prolidase-Sepharose 4B was prepared using cyanogen bromide-activated Sepharose 4B (Pharmacia, Uppsala, Sweden) according to the manufacturer's description. The gel preparation containing $2 \mathrm{mg}$ of purified prolidase per $\mathrm{ml}$ of Sepharose $4 \mathrm{~B}$ was used to isolate the 
specific IgG that binds to prolidase from the anti-prolidase rabbit serum. Immobilized mouse IgGs on agarose beads were prepared using purified IgGs and cyanogen bromide-activated Sepharose 4B (1 mg of purified IgG per $\mathrm{ml}$ ).

The cDNA insert (PL-21) corresponding to human prolidase mRNA was cloned and characterized (8). It was found to cover nearly the full length of the coding region and $3^{\prime}$ noncoding region of the mRNA and was used as a probe for RNA blotting analysis. The DNA probe was radiolabeled as described (10). $\left[\alpha-{ }^{32} \mathrm{P}\right] \mathrm{CTP}(3,000 \mathrm{Ci} / \mathrm{mmol})$ and $\left[{ }^{35} \mathrm{~S}\right]$ methionine $(1,100 \mathrm{Ci} / \mathrm{mmol})$ were purchased from $\mathrm{ICN}$ radiochemicals (Irvine, CA). Nitrocellulose membranes were obtained from Schleicher and Schuell (Dassel, FRG).

Preparation of cell extracts. Confluently cultured monolayers of skin fibroblasts cultured as described (11) were collected by a rubber policeman and washed three times with PBS. The cell pellets were suspended in ice-cold PBS and then disrupted by sonication (Handy Sonic UR-20P; Tomy Seiko Co. Ltd., Tokyo, Japan). The EBV-transformed lymphoblastoid cells were cultured as described (12), washed three times with PBS, and sonicated. The disrupted cells were centrifuged at $12,000 \mathrm{~g}$ for $3 \mathrm{~min}$ and the supernatants were used for further analyses.

Immunoblot analyses. The extracts ( $100 \mu \mathrm{g}$ protein) were mixed with agarose gel ( $50 \mu \mathrm{l}$ of $1: 1$ suspension) that contained covalently bound mouse monoclonal IgGs to immunoprecipitate the prolidase. The suspensions were incubated for $1 \mathrm{~h}$ at room temperature on an end-to-end rotor, centrifuged, and the pellets washed three times with 1 $\mathrm{ml}$ of ice-cold $50 \mathrm{mM}$ Tris-HCl buffer, $\mathrm{pH}$ 7.0. Finally, the pellets were mixed with an equal volume of $125 \mathrm{mM}$ Tris-HCl, pH 6.8, 4\% SDS (wt/vol), $10 \%$ (vol/vol) glycerol, and $2 \%$ (vol/vol) mercaptoethanol. The suspensions were placed in a boiling water bath for $1 \mathrm{~min}$, cooled at room temperature, and centrifuged. A sample of the supernatant was subjected to SDS-PAGE. Alternatively, the cell extracts $(100 \mu \mathrm{g}$ protein) were directly subjected to SDS-PAGE. Transfer of proteins to nitrocellulose membranes was done according to Towbin et al. (13). The nitrocellulose membranes were incubated with $0.5-1 \mu \mathrm{g} / \mathrm{ml}$ antiprolidase rabbit IgG. The rabbit IgG was detected as described (5).

Analysis of $\left[{ }^{35} \mathrm{~S}\right]$ methionine-labeled prolidase. Confluently cultured fibroblasts in $75-\mathrm{cm}^{2}$ flask were preincubated in $5 \mathrm{ml}$ methionine-free medium including 10\% dialyzed FCS (Gibco Laboratories, Grand Island, NY) for 60 min and then pulse-labeled with $\left[{ }^{35}\right.$ S $]$ methionine $(100 \mu \mathrm{Ci})$ at $37^{\circ} \mathrm{C}$ in $4 \mathrm{ml}$ of the same medium. Similarly, cultured lymphoblastoid cells $\left(10^{6}\right)$ were preincubated in $2 \mathrm{ml}$ of methionine-free medium for $2 \mathrm{~h}$ at $37^{\circ} \mathrm{C}$ in $5 \% \mathrm{CO}_{2}$ and pulse-labeled with $\left[{ }^{35} \mathrm{~S}\right]$ methionine in a total vol of $4 \mathrm{ml}$. The cells were washed with ice-cold PBS lysed by sonication in a buffer containing $50 \mathrm{mM}$ Tris $\mathrm{HCl}, \mathrm{pH} 7.4,0.1 \%$ Triton X-100, $2 \mathrm{mM}$ PMSF, $10 \mu \mathrm{g} / \mathrm{ml}$ leupeptin, and $0.1 \mathrm{mg} / \mathrm{ml}$ aprotinin.

Immunoprecipitation of labeled prolidase with the polyclonal antibody was carried out as follows. An amount of rabbit IgG sufficient to precipitate labeled prolidase was added to the supernatant of the cultured cells. The mixture was incubated at $37^{\circ} \mathrm{C}$ for $60 \mathrm{~min}$, then $50 \mu \mathrm{l}$ of the suspension of protein A-agarose ( $50 \% \mathrm{vol} / \mathrm{vol}$; Pharmacia) was added. The incubation was continued for $60 \mathrm{~min}$ at room temperature on the end-to-end rotor. At the end of the incubation the gel was washed three times with $1 \mathrm{ml}$ of $50 \mathrm{mM}$ Tris- $\mathrm{HCl}, \mathrm{pH} 7.0$, containing $0.1 \%$ Triton X-100, $0.05 \%$ SDS, and proteinase inhibitors. The immunoprecipitates were separated by SDS-PAGE and the gels were analyzed by fluorography.

$S D S-P A G E$. Electrophoresis of proteins was carried out in $10 \%$ polyacrylamide gels containing $0.1 \%$ SDS (14). Gels were calibrated with the following molecular weight standards: phosphorylase $b$, 92,500; BSA, 66,000; ovalbumin, 43,000; and catalase, 35,000. For the fluorography, each slab gel was soaked in $\mathrm{EN}^{3} \mathrm{HANCE}$ (New England Nuclear, Boston, MA) for $1 \mathrm{~h}$ at room temperature, washed for $30 \mathrm{~min}$ with cold distilled water, dried, and placed in contact with an $\mathrm{x}$-ray film (Kodak X-Omat) at $-70^{\circ} \mathrm{C}$ for $36-120 \mathrm{~h}$.

RNA blot analysis. Total RNA was isolated from the cultured cells by a guanidine thiocyanate procedure and analyzed by blotting after electrophoresis in formamide-containing agarose gels $(1 \%)$ as described (15). Conditions for hybridization and washing were as described (8).

Enzyme assay. Imidodipeptide-hydrolyzing activities were measured using glycyl-L-proline, L-alanyl-L-proline, and L-leucyl-L-proline as substrates. The activities in the crude cell extracts were measured at $37^{\circ} \mathrm{C}$ in a total vol of $250 \mu \mathrm{l}$ containing $0.1 \mathrm{M}$ Tris- $\mathrm{HCl}, \mathrm{pH} \mathrm{8.0,10}$ $\mathrm{mM} \mathrm{MnCl}$, and $10 \mathrm{mM}$ of a substrate peptide after $15 \mathrm{~min}$ of preincubation unless otherwise stated. The proline released from the peptides was assayed by the method of Chinard (16) as described (17).

For the immune titration of prolidase activity, various amounts of mouse or rabbit IgG were incubated with the crude cell extracts for $1 \mathrm{~h}$ at room temperature and a 50- $\mu$ l suspension of protein A agarose (1:1) was added. The enzyme activity in the supernatant was then measured. The enzyme activity that bound to mouse IgG EP2 was measured as follows: the samples were prepared by incubating the crude cell extracts and EP2-agarose at room temperature for $1 \mathrm{~h}$. The gel was washed three times with $50 \mathrm{mM}$ Tris- $\mathrm{HCl}, \mathrm{pH} 7.6$, containing $10 \mathrm{mM}$ $\mathrm{MnCl}_{2}$. The gel suspension was preincubated for $15 \mathrm{~min}$ at $37^{\circ} \mathrm{C}$ and the substrate peptides were added. After an appropriate incubation time at $37^{\circ} \mathrm{C}$, with vigorous shaking, the supernatant was collected and used for the determination of proline. Mouse IgG EP2 did not inhibit the enzyme activity of prolidase. Alternatively, the prolidase was eluted from the gel with $0.1 \mathrm{M} \mathrm{Na}_{2} \mathrm{CO}_{3}$ for enzyme assay (9).

Patients. Cultured skin fibroblasts or cultured lymphoblastoid cells were obtained from eight patients with prolidase deficiency. Clinical features are summarized in Table I. Two patients died (cases 2 and 4) and skin lesions were present in all the patients. In severe cases there were deep skin ulcers or lymphedema. Mild skin lesions included eruption, teleangiectagia, and pigmentation. Two of the first cousins of the case 5 patient had a prolidase deficiency with similar skin lesions and other clinical features. Skin lesions of the case 7 patient were present from $19 \mathrm{mo}$, while her sister (case 8) had no prominent changes in the skin until $18 \mathrm{yr}$.

\section{Results}

Fig. $1 A$ shows the immune titration of imidodipeptide-hydrolyzing activities with mouse IgG EP2 in crude extracts from a control fibroblast cell strain. Most of the imidodipeptide-hydrolyzing activity was immunoprecipitated. When the enzyme activity in the supernatant was measured without preincubation a small amount of activity was detected (Tables II and III). This activity remained in the supernatant after immunoprecipitation with the polyclonal rabbit IgG or other monoclonal mouse IgGs (EP10 and EP38). The activity of prolidase was not inhibited when mouse IgG-EP2 was added to the mixture (Fig. 1 $A$ ). As described below, the substrate specificities of the activities in the supernatant and in the immunoprecipitates differed. L-Alanyl-L-proline was used as a substrate in this experiment, since this peptide was suitable to detect both activities.

Immunoblot analyses of the immunoprecipitated fraction and the supernatant obtained from the control cells are shown in Fig. $1 \mathrm{~B}$. The precipitate contained a protein of $M_{\mathrm{r}} 56,000$ that crossreacted with the polyclonal antibody. The supernatant, however, did not. The $M_{\mathrm{r}} 56,000$ protein was the subunit derived from prolidase $(5,9)$. The imidodipeptide-hydrolyzing activity in the supernatant showed a different substrate specificity from the immunoprecipitated enzyme (Table II). The enzyme activity in the supernatant seemed to correspond to the labile enzyme reported by Butterworth and Priestman (4). The labile enzyme could be separated from prolidase by DEAE cellulose column chromatography (4). We confirmed that the labile enzyme did not crossreact with antiprolidase monoclo- 


\begin{tabular}{|c|c|c|c|c|c|c|c|c|c|c|}
\hline \multirow[b]{2}{*}{ Case } & \multirow[b]{2}{*}{ Sex } & \multirow[b]{2}{*}{ Age } & \multirow{2}{*}{$\begin{array}{c}\text { Onset of } \\
\text { symptoms }\end{array}$} & \multirow[b]{2}{*}{ Initial symptoms } & \multicolumn{4}{|c|}{ Clinical symptoms } & \multirow{2}{*}{$\begin{array}{l}\text { Consanguinity } \\
\text { (family history) }\end{array}$} & \multirow[b]{2}{*}{ References } \\
\hline & & & & & Skin & MR & BJ & Splenomegaly & & \\
\hline & & $y r$ & & & & & & & & \\
\hline 1 & Male & 8 & Early infancy & Skin, hypotonia & $\begin{array}{c}+ \\
\text { Moderate }\end{array}$ & - & + & - & $\begin{array}{l}- \\
(-)\end{array}$ & 26 \\
\hline 2 & Female & Died at 36 & $7 \mathrm{yr}$ & Skin, splenomegaly & $\begin{array}{c}+ \\
\text { Severe }\end{array}$ & - & - & $\begin{array}{c}+ \\
\text { (Splenectomy) }\end{array}$ & $\begin{array}{l}- \\
(-)\end{array}$ & 27 \\
\hline 3 & Male & 21 & $3 \mathrm{mo}$ & Skin & $\begin{array}{c}+ \\
\text { Severe }\end{array}$ & \pm & - & - & $\stackrel{+}{(-)}$ & 18 \\
\hline 4 & Male & Died at 15 & $2 \mathrm{mo}$ & $\begin{array}{l}\text { Diarrhea, } \\
\text { thrombocytopenia, } \\
\text { splenomegaly }\end{array}$ & $\stackrel{+}{+}$ & - & - & + & $(-)$ & \\
\hline 5 & Female & 38 & $5-7 \mathrm{yr}$ & Skin & $\begin{array}{c}+ \\
\text { Severe }\end{array}$ & + & + & + & $\begin{array}{c}+ \\
(+)\end{array}$ & 28,29 \\
\hline 6 & Male & 18 & $10 \mathrm{yr}$ & Skin & $\begin{array}{c}+ \\
\text { Severe }\end{array}$ & + & - & - & $\begin{array}{l}+ \\
(-)\end{array}$ & 19 \\
\hline 7 & Female & 25 & $19 \mathrm{mo}$ & Skin & $\stackrel{+}{+}$ & - & - & - & $\begin{array}{c}+ \\
(+)\end{array}$ & 30 \\
\hline 8 & Female & 18 & $18 \mathrm{yr}$ & Skin & $\begin{array}{c}+ \\
\text { Mild }\end{array}$ & - & - & - & $\begin{array}{c}+ \\
(+)\end{array}$ & 30 \\
\hline
\end{tabular}

MR, mental retardation; BJ, abnormalities of bones and joints.

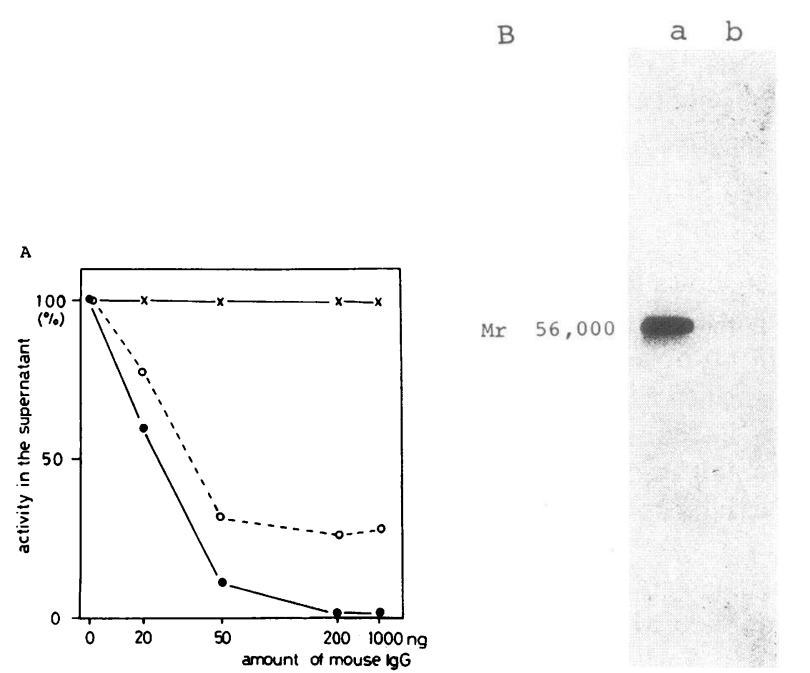

Figure 1. Presence of imidopeptide-hydrolyzing activity not immunoprecipitated with anti-prolidase monoclonal mouse IgG-EP2 in the crude extract of control fibroblasts. The crude extract from control fibroblasts was subjected to immunoprecipitation with EP2 and protein A-agarose. $A$, The imidopeptide-hydrolyzing activities were measured in the supernatant after immunoprecipitation $(0, \bullet)$ or in the mixture before the addition of protein A-agarose $(\dot{X})$. The activities were measured as described in Methods $(\bullet, \dot{X})$ or without preincubation (o). Reactions were carried out in the presence of $\mathrm{MnCl}_{2}$ in both assays and as described in Methods. $50 \mathrm{mM}$ L-Alanyl-L-proline was used as the substrate. The activities were expressed by percentage of the initial ones. $B$. The immunopreciptate and the supernatant obtained with $1,000 \mathrm{ng}$ of mouse IgG were analyzed for the subunit of prolidase by means of prolidase of immunoblotting. Lane $a$, immunoprecipitate; $b$, supernatant. The subunit of prolidase was detected using anti-prolidase rabbit IgG as described in Methods. Note that the subunit of prolidase $\left(M_{\mathrm{r}} 56,000\right)$ is specifically stained in lane $a$. nal and polyclonal antibodies. Thus, the activity in the supernatant obtained after the immunoprecipitations represented the labile imidodipeptidase.

The crude extracts from the controls' and patients' cells were subjected to immunoprecipitation. The enzymic activities remaining in the supernatant were measured using glycylL-proline, L-alanyl-L-proline, and L-leucyl-L-proline as substrates (Tables II and III). In cases 1 and 2 part of the activity toward glycyl-L-proline or leucyl-L-proline was immunopre-

Table II. Enzymic Activities of the Prolidase and the Labile Enzymes in Cultured Skin Fibroblasts

\begin{tabular}{lcccccccc}
\hline & & \multicolumn{7}{c}{ Case } \\
\cline { 3 - 8 } & \multicolumn{1}{c}{ Controls* } & 1 & 2 & 3 & 4 & 7 & 8 \\
\hline \multicolumn{7}{c}{ Prolidase (immunoprecipitated with EP2) } \\
Gly-pro & $139.3 \pm 10.6$ & 4.2 & 1.0 & 0 & 0 & 0 & 0 \\
Ala-pro & $74.6 \pm 6.2$ & 1.5 & 1.2 & 0 & 0 & 0 & 0 \\
Leu-pro & $54.6 \pm 7.1$ & 1.8 & 4.2 & 0 & 0 & 0 & 0 \\
Labile enzyme (supernatant) & & & & & & \\
Gly-pro & $9.2 \pm 3.8$ & 3.4 & 2.9 & 4.4 & 2.4 & 3.0 & 3.2 \\
Ala-pro & $16.2 \pm 5.3$ & 5.6 & 4.4 & 8.2 & 3.4 & 6.5 & 6.0 \\
Leu-pro & $8.3 \pm 2.4$ & 3.4 & 0.7 & 5.2 & 2.8 & 3.7 & 3.0
\end{tabular}

* Control values are from three cell strains (mean \pm SD). Other values are the mean of triplicate determinations. Prolidase activities were measured using immune precipitates as a source of the enzyme. Activities remaining in the supernatant after immunoprecipitation are referred to as the labile enzyme. Activities of the labile enzyme were assayed without preincubation. Enzymic activities were expressed as nanomoles/milligram protein per minute. Other conditions of the assay are described in Methods. 
Table III. Enzymic Activities of the Prolidase and the Labile Enzyme in Cultured Lymphoblastoid Cells

\begin{tabular}{cccc} 
& Control & Case 5 & Case 6 \\
\hline \multicolumn{2}{c}{ Prolidase (immunoprecipitated } & with EP2) & \\
Gly-pro & 66.0 & 0 & 0 \\
Ala-pro & 27.4 & 0 & 0 \\
Leu-pro & 23.1 & 0 & 0 \\
Labile enzyme (supernatant) & & \\
Gly-pro & 7.6 & 4.1 & 4.8 \\
Ala-pro & 15.3 & 7.1 & 6.6 \\
Leu-pro & 7.2 & 4.4 & 2.1
\end{tabular}

Values are the mean of triplicate determinations. The enzymic activities are expressed as nanomoles/milligram protein per minute. Prolidase and the labile enzyme were separated and measured as described in the footnote to Table I and in Methods.

cipitated by mouse IgG-EP2 (Table II). In cases 3-8 no activity was immunoprecipitated. The remaining imidodipeptide-hydrolyzing activities in the supernatant from these cells was not immunoprecipitated by adding polyclonal antibody (not shown). These immunochemical studies on human cultured fibroblasts and lymphoblastoid cells confirmed that there are at least two different enzymes that hydrolyze imidodipeptides. The major enzyme, prolidase, was impaired in cells from prolidase-deficient subjects. The supernatant activity from the patients' cells preferentially hydrolyzed L-alanyl-L-proline as was demonstrated in the control cells; however, the activities were lower than in the control $(30-60 \%$ of control; Tables II and III).

The immune complexes prepared with EP2-agarose and the crude extracts of the cell strains of cases 1 and 2 contained imidodipeptide-hydrolyzing activity (Table II). The enzyme from case 1 preferentially hydrolyzed glycyl-L-proline and the enzyme from case 2, L-leucyl-L-proline (Table II). These activities seemed to represent the mutant enzymes in these two cell strains. The activity associated with EP2-agarose could be eluted with $0.1 \mathrm{M} \mathrm{Na}_{2} \mathrm{CO}_{3}$ without loss of the activity. The putative-mutant enzymes were eluted from EP2-agarose and studied for substrate specificities. The activities and the substrate specificities of the enzymes in each cell strain were similar to those obtained using immune complexes (not shown).

Immune proteins precipitated with EP2-agarose from the cultured fibroblasts and lymphoblastoid cells were studied by immunoblotting (Fig. 2, $A, C$, and $E$ ). In the lane related to control cells, a protein with $M_{\mathrm{r}} 56,000$ was specifically stained. Samples from cases 1 and 2 contained immunologically crossreacting materials (CRM). ${ }^{1}$ Sizes of the CRM were the same as that of the control. In other experiments the crude extracts of the cultured cells were analyzed directly by immunoblotting (Fig. 2, $B, D$, and $F$ ). These results suggest that cells from cases 3-8 patients did not contain CRM when examined using immunoblots. An analysis of erythrocytes from the case 6 patient revealed the absence of CRM (not shown).

Metabolic labeling of the fibroblasts followed by immunoprecipitation of prolidase was done to investigate the biosyn-

1. Abbreviation used in this paper: CRM, crossreacting materials. thesis of prolidase. When control cells were pulse-labeled for 1 $\mathrm{h}$ a protein with $M_{\mathrm{r}} 56,000$ was recognized (Fig. 3). The molecular mass of this labeled protein did not change during a 1-h chase. Thus, the subunit of prolidase was synthesized as a polypeptide with $M_{\mathrm{r}} 56,000$, findings similar to those for the mature enzyme. No major processing occurred.

The fibroblast cell strains and the lymphoblastoid cells from patients with a prolidase deficiency (except for cases 7 and 8 ) were analyzed by metabolic labeling (Fig. 4). Cell strains from cases 1 and 2 synthesized a polypeptide with $M_{\mathrm{r}}$ 56,000 ; however, the other strains synthesized no immunologically crossreacting polypeptide. The results of immunoblot analyses and metabolic labeling experiments suggested that cell strains from cases $3,4,5$, and 6 either did not synthesize CRM or synthesized only an unstable polypeptide.

Northern blot hybridization was used to determine prolidase gene expression in the fibroblast cell strains and lymphoblastoid cell strains (Fig. 5). A cDNA insert that covered most of the coding region and the $3^{\prime}$ noncoding region was radiolabeled and used as a probe. In the lane containing the total RNA from the control cells a 2.3-kb band was observed. Lanes that contained the same amount of total RNA showed a radiolabeled band of the same size (cases 1 and 2). On the other hand, mRNA corresponding to prolidase was not detected in cells from other patients. RNA preparations from the fibroblast strains of cases 7 and 8 were not available.

Thus, we analyzed eight cell strains from seven families with clinically manifested prolidase deficiency. Two were CRM positive and the others were CRM negative. CRM-positive cells possessed weak but detectable activities of prolidase. CRM-negative cell strains were mRNA negative. The biochemical phenotypes are summarized in Table IV.

\section{Discussion}

Our series of experiments revealed that human prolidase is a homodimer with an estimated $M_{\mathrm{r}}$ of 56,000 as determined by SDS-PAGE $(5,9)$, and the subunit composed of 492 amino acid residues has an $M_{\mathrm{r}}$ of 54,305 (8). The cDNA codes 493 amino acid residues, and in the mature enzyme the $\mathrm{NH}_{2}$-terminal methionine is removed and the newly appearing $\mathrm{NH}_{2}-$ terminal alanine is acylated, probably acetylated (8). There is no evident processing on the carboxyl terminus and there are two possible glycosylation sites on the polypeptide (8). We observed biosynthesis of prolidase within fibroblasts and lymphoblasts from controls. Pulse and chase experiments revealed that the subunit of prolidase is synthesized as a polypeptide with $M_{\mathrm{r}} 56,000$, similar to findings with the purified enzyme $(5,9)$. These findings are compatible with data obtained in studies on fibroblasts (6). All these results suggest that both the processing of the polypeptide (as expected from the previous study) and glycosylation were minimal.

We reported that the subunit protein of prolidase was absent in erthrocytes of a Japanese subject with prolidase deficiency (5). The subunit protein and the corresponding mRNA in the cultured lymphoblastoid cells from the same patient were absent (case 5). In addition, we analyzed both the erythrocytes and the cultured lymphoblastoid cells from the case 6 patient and noted that CRM was absent in both types of cells. mRNA was absent in the lymphoblastoid cells from the case 6 patient. These results suggest that genetic defects in prolidase deficiency are equally expressed in these cells. 


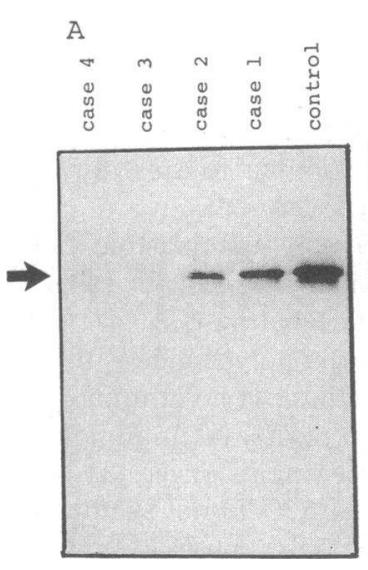

C
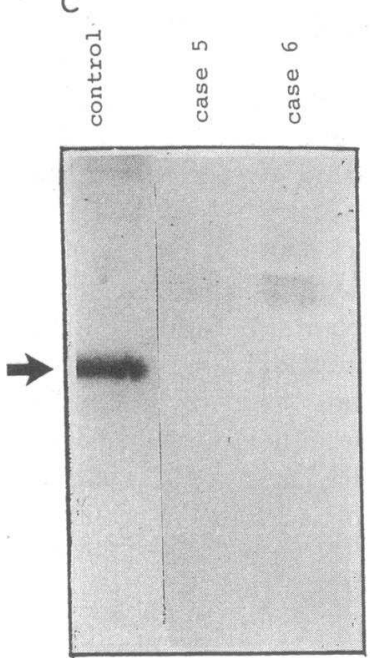

$\mathrm{E}$
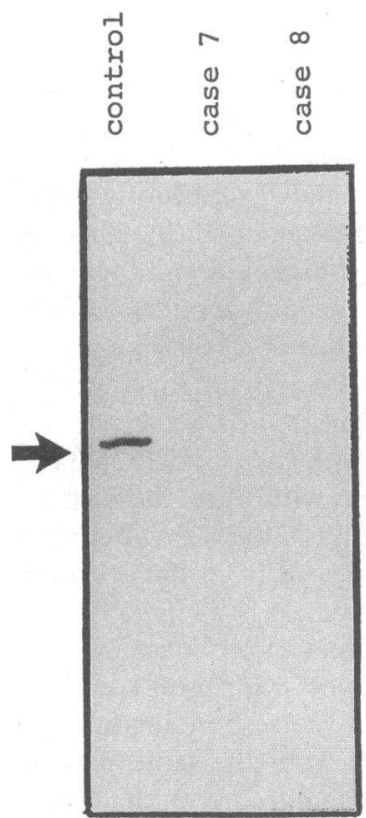

Figure 2. Immunoblot analyses of prolidase in cultured skin fibroblasts and in cultured lymphoblastoid cells from patients with prolidase deficiency. The crude extracts ( $100 \mu \mathrm{g}$ protein) were treated with EP2-agarose ( $50 \mu$ l of $1: 1$ suspension) before gel electrophoresis $(A, C, E)$ or subjected directly to the gel electrophoresis $(B, D, F)$ as

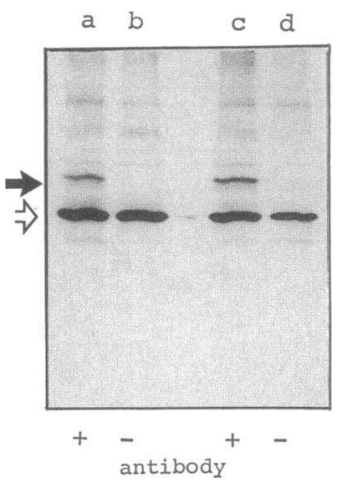

Figure 3. Biosynthesis of the subunit of prolidase in control fibroblasts. The fibroblasts were pulse-labeled for 60 min (lanes $a$ and $b$ ), or pulse-labeled for $60 \mathrm{~min}$ and chased for 60 min with methionine-containing medium (lanes $c$ and $d$ ). Cell extracts were treated with affinity-purified rabbit IgG directed to prolidase (lanes $a$ and $c$ ) or preimmune rabbit IgG (lanes $b$ and $d$ ) as described in Methods. Radiolabeled protein of $M_{\mathrm{r}}$ 56,000 was immunoprecipitated in lanes $a$ and $c$ as indicated by the

black arrow. The nonspecifically precipitated protein is indicated by the white arrow.

The genetic heterogeneity in prolidase deficiency was demonstrated by the specific assay of prolidase, immunoblot, and metabolic labeling analyses of the enzyme protein, and analyses of mRNA by Northern blotting in the cultured cells. Two of the eight patients were CRM positive. In the two CRM-positive cell strains, biosynthesis of the polypeptides was similar to that of control; hence, there may be a single amino acid substitution among the mutant enzymes. These results are in accord with those obtained from immunoblot analyses in which the decreased amount of the $M_{\mathrm{r}} 56,000$ polypeptide was specifically demonstrated in both cell types. Northern blots revealed a normal size of mRNAs in both cell types. The difference in substrate specificities seen with the two mutant enzymes may indicate different mutations, although the active site of the enzyme does relate to both mutations. Boright et al. (6) reported a case with high molecular weight polypeptide that crossreacted with anti-prolidase antibody. These data indicate that a genetic heterogeneity is present among the CRM-positive patients.

These studies support the proposal that prolidase deficiency is caused by a genetic defect within the prolidase gene. Prolidase deficiency is a syndrome characterized by a variety of abnormalities in organs and tissues. One of the main questions is whether the disorder is caused by a defect in the prolidase gene or whether another gene is involved. Prolidase was absent in the mRNA in four patients with prolidase deficiency. Thus, the defect in the protein might be associated with a defect in expression of the gene. The abnormal enzymes in two patients suggest that the mutations might be localized at the prolidase gene.

Severities of enzyme defects have been speculated, based on results of prolidase assays with extracts from cells including peripheral erythrocytes $(2,3,17-21)$, leukocytes $(21,22)$, cultured skin fibroblasts $(4,18,23,24)$, and cultured lymphoblastoid cells (18). However, human cells contain a labile activity other than prolidase toward imidodipeptides $(4,23)$ and levels of the labile activity vary with the cell and tissue (4). As a specific assay of prolidase was required to assess severity of the enzyme defects, we made use of an immunochemical proce-

described in Methods. The following samples were analyzed: $A$ and $B$, cultured skin fibroblasts from control and cases $1-4$. $C$ and $D$, cultured lymphoblastoid cells from control and cases 5 and 6. $E$ and $F$, cultured skin fibroblasts from control and cases 7 and 8 . Cases 7 and 8 were siblings. Arrows indicate size of the subunit of prolidase, $M_{\mathrm{r}} 56,000$ 


\section{B}

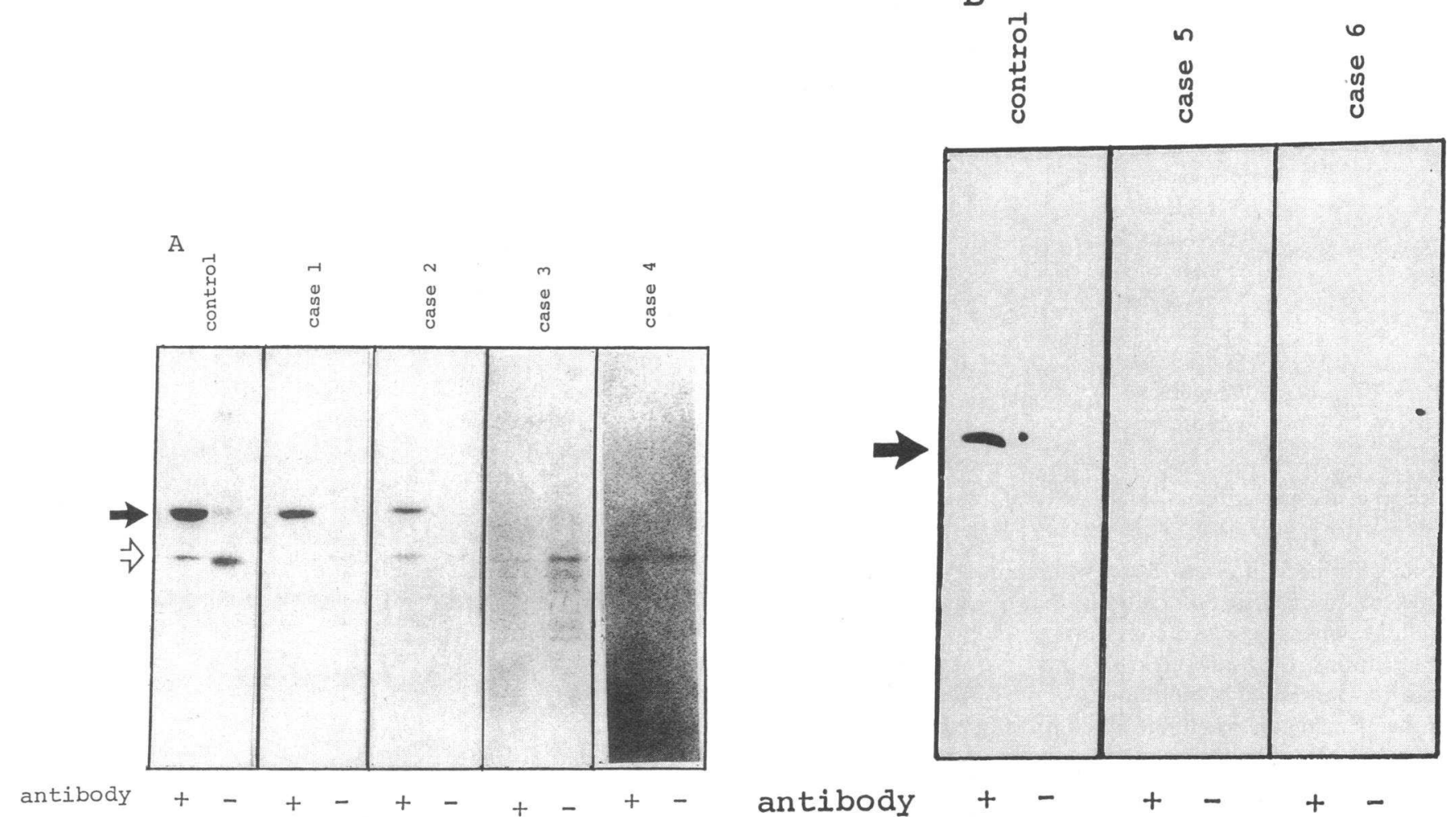

Figure 4. Biosynthesis of the subunit of prolidase in cultured skin fibroblasts or cultured lymphoblastoid cells from patients with prolidase deficiency and from controls. The cultured skin fibroblasts $(A)$ or the cultured lymphoblastoid cells $(B)$ were pulse-labeled with $\left[{ }^{35} S\right]$ methionine for $6 \mathrm{~h}$ and chased for $1 \mathrm{~h}$. The cell extracts were treated with the affinity-purified rabbit IgG or preimmune IgG. The immunoprecipitates were analyzed as described in Methods. The black arrows indicate the size of the subunit of prolidase, $M_{\mathrm{r}} 56,000$. The nonspecifically precipitated protein is indicated by the white arrow.

dure to observe residual activity of the defective enzyme in the CRM-positive cells and the absence of the prolidase activity in the CRM-negative cells. Thus, we could compare the clinical symptoms with the residual activity of prolidase.

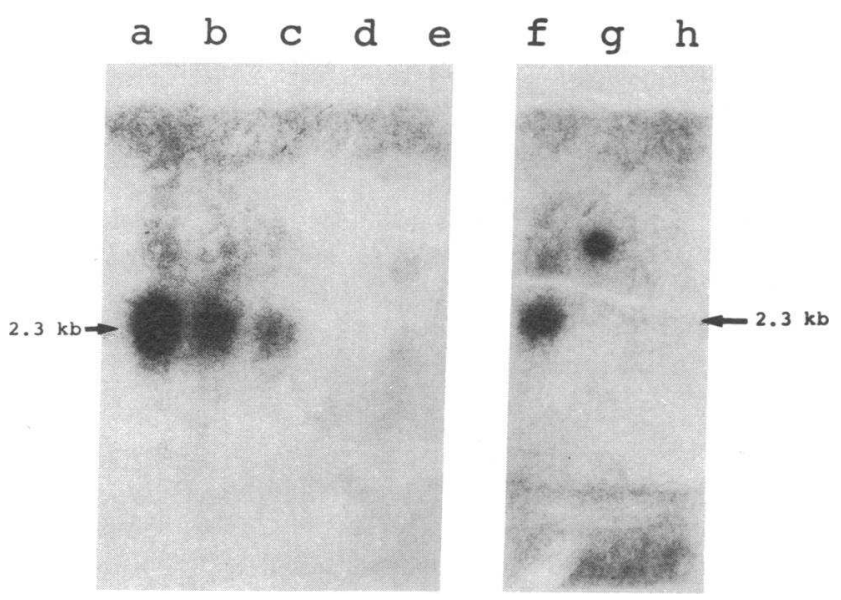

Figure 5. Northern blot analyses of RNA obtained from cultured skin fibroblasts and the cultured lymphoblastoid cells. Total RNA was prepared and analyzed as described in Methods. Each lane contained $10 \mu \mathrm{g}$ of total RNA obtained from cultured skin fibroblasts (lanes $a-e$ ) or cultured lymphoblastoid cells (lanes $f-h$ ). Lanes $a$ and $f$, control; $b$, case $1 ; c$, case $2 ; d$, case 3 ; $e$, case $4 ; g$, case $5 ; h$, case 6 . The arrow indicates the size of mRNA corresponding to the subunit of prolidase $(2.3 \mathrm{~kb})$.
The age at onset of the clinical symptoms did not correlate with the severity of the enzyme defect. The mental development possibly reflects the severity of the biochemical defect since mental retardation occurred only in the CRM-negative patients; however, the absence of CRM is not always associated with mental retardation. The mutant prolidases in the CRM-positive cells showed low levels of enzyme activity, but this residual activity may be too minimal to alter imidodipeptide metabolism in the skin and collagenous tissues.

The labile enzyme probably plays some role in metabolism of the imidodipeptides. Our study provided evidence that the labile enzyme is not immunologically related to prolidase. These two enzymes, the prolidase and the labile enzyme, represent different polypeptides; hence, the structural gene must be different.

Butterworth and Priestman (4) described abnormal natures of the labile enzyme in prolidase-deficient cells. Boright et al. (6) reported that the hydrolyzing activity against glycyl-L-proline was $\sim 5 \%$ normal in CRM-negative cells, thereby indicating the presence of the labile enzyme. Our approaches, presented in this study, facilitated assessment of the activity of the labile enzyme even in the control and the CRM-positive cells. Our data show that the labile activities are equally decreased in CRM-positive and -negative cells. However, these enzyme assays do not allow for estimation of the total imidopeptidehydrolyzing activity in vivo in the patients and the control.

An interpretation for the decreased activities of the labile enzyme in the patients' cells is difficult since knowledge of the 


\begin{tabular}{|c|c|c|c|c|c|}
\hline \multirow[b]{2}{*}{ Case } & \multirow[b]{2}{*}{ Cells } & \multirow[b]{2}{*}{ Prolidase activity } & \multicolumn{2}{|c|}{ Polypeptide } & \multirow[b]{2}{*}{ mRNA } \\
\hline & & & Immunoblot & Biosynthesis & \\
\hline 2 & Fibroblasts & $0.7-7.6 \%$ of control* & Present & Present & Present \\
\hline 3 & Fibroblasts & 0 & Absent & Absent & Absent \\
\hline 4 & Fibroblasts & 0 & Absent & Absent & Absent \\
\hline \multirow[t]{2}{*}{5} & Lymphoblastoid cells & 0 & Absent & Absent & Absent \\
\hline & Erythrocytes & 0 & Absent & - & - \\
\hline \multirow[t]{2}{*}{6} & Lymphoblastoid cells & 0 & Absent & Absent & Absent \\
\hline & Erythrocytes & 0 & Absent & - & - \\
\hline 7 & Fibroblasts & 0 & Absent & ND & ND \\
\hline 8 & Fibroblasts & 0 & Absent & ND & ND \\
\hline
\end{tabular}

* Range of enzymic activities against different substrate peptides.

labile enzyme is limited. Butterworth and Priestman speculated, based on their observations, that the labile enzyme and prolidase might possess a common subunit (4). However, our observations ruled out this possibility. We assume that prolidase may be related to the stability of the labile enzyme in vivo or that gene regulation of the labile enzyme may be influenced by factors that relate to prolidase activity.

Regarding the clinical heterogeneity of prolidase deficiency, the role of the labile enzyme has to be clarified. It is tempting to speculate that among individuals with a prolidase deficiency and various activities of the labile enzyme, those with decreased levels may develop clinical symptoms of prolidase deficiency. However, our data of the siblings (cases 7 and 8 of prolidase deficiency with different degrees of severity of skin lesions) do not support this proposal. The case 7 patient developed skin lesions at age 19 mo and specific treatment was required, whereas her sister (case 8 ) had no prominent change in the skin until age $18 \mathrm{yr}$. Both were CRM negative and there were no residual activities of prolidase in the fibroblasts. The total imidopeptide-hydrolyzing activities of two cell strains were similar (Table II). The imidodipeptide-hydrolyzing activities in sera of siblings was reported to be similar (25). These activities in the sera may represent the labile enzyme since these two patients were CRM negative and the substrate specificity of the activity resembled that of the labile enzyme (25). The labile enzyme in this family may not itself be a major factor modifying development of skin lesions.

Thus, our data suggest that the labile enzyme seems to be largely irrelevant as a biochemical basis for this metabolic disorder. Further studies are needed to clarify the mechanisms of the heterogeneous expression of the genetic defects in relation to this specific disorder.

Cloning of genomic DNA for the prolidase gene is ongoing in our laboratory. The prolidase gene is extremely large in humans and possible pseudogenes have to be identified (Tanoue, A., F. Endo, and I. Matsuda, manuscript in preparation).

\section{Acknowledgments}

We thank Dr. I. Akaboshi for advice on the cell culture, M. Izumida for assistance with the cell cultures, $M$. Hongo and $M$. Hayashi for secretarial services, and M. Ohara for helpful comments.

This work was supported in part by a grant in aid from the Ministry of Education of Japan and the Ministry of Health and Welfare and in part by a research grant from IBM Japan and Biotechnology Suishinkai.

\section{References}

1. Phang, J. M., and C. R. Scriver. 1989. Disorders of proline and hydroxyproline metabolism. In The Metabolic Basis of Inherited Disease. C. R. Scriver, A. L. Beudet, W. S. Sly, and D. Valle, editors. McGraw-Hill Inc., New York. 577-597.

2. Umemura, S. 1987. Studies on a patient with imidodipeptiduria. II. Lack of prolidase activity in blood cells. Physiol. Chem. Phys. 10:279-283.

3. Isemura, M., T. Hanyu, F. Gejyo, R. Nakazawa, R. Igarashi, S. Matsuo, K. Ikeda, and Y. Sato. 1979. Prolidase deficiency with imidodipeptiduria: a familial case with and without clinical symptoms. Clin. Chim. Acta. 93:401-407.

4. Butterworth, J., and D. A. Priestman. 1985. Presence in human cells and tissues of two prolidases and their alteration in prolidase deficiency. J. Inherited Metab. Dis. 8:193-197.

5. Endo, F., K. Motohara, Y. Indo, and I. Matsuda. 1987. Immunochemical studies of human prolidase with monoclonal and polyclonal antibodies: absence of the subunit of prolidase in a patient with prolidase deficiency. Pediatr. Res. 22:627-633.

6. Boright, A. P., C. R. Scriver, G. A. Sancaster, and F. Choy. 1989. Prolidase deficiency: biochemical classification of alleles. Am. J. Hum. Genet. 44:731-740.

7. Endo, F., A. Hata, Y. Indo, K. Motohara, and I. Matsuda. 1987. Immunochemical analyses of prolidase deficiency and molecular cloning of a cDNA for prolidase of human liver. J. Inherited Metab. Dis. 10:305-307.

8. Endo, F., A. Tanoue, H. Nakai, A. Hata, Y. Indo, K. Titani, and I. Matsuda. 1989. Primary structure and gene localization of human prolidase. J. Biol. Chem. 264:4476-4481.

9. Endo, F., A. Tanoue, T. Ogata, K. Motohara, and I. Matsuda. 1988. Immunoaffinity purification of human prolidase. Clin. Chim. Acta. 176:143-150.

10. Feinberg, A. P., and B. Vogelstein. 1984. A technique for radiolabeling DNA restriction endonuclease fragments to high specific activity. Anal. Biochem. 137:266-267.

11. Kitano, A., F. Endo, I. Matsuda, S. Miyabayashi, and H.-H. M. Dahl. 1989. Mutation of the $E_{1 \alpha}$ subunit of the pyruvate dehydrogenase complex, in relation of heterogeneity. J. Inherited Metab. Dis. 12:97-107.

12. Indo, Y., A. Kitano, F. Endo, I. Akaboshi, and I. Matsuda. 1987. Altered kinetic properties of the branched-chain $\alpha$-keto acid dehydrogenase complex due to mutation of the $\beta$-subunit of the 
branched-chain $\alpha$-keto acid decarboxylase $\left(\mathrm{E}_{1}\right)$ component in lymphoblastoid cells derived from patients with maple syrup urine disease. $J$. Clin. Invest. 80:63-70.

13. Towbin, H., T. Staelin, and J. Gordon. 1979. Electrophoretic transfer of proteins from polyacrylamide gels to nitrocellulose sheets: procedure and some applications. Proc. Natl. Acad. Sci. USA. 76:4350-4354.

14. Laemmli, U. K. 1970. Cleavage of structural proteins during the assembly of head of bacteriophage T4. Nature (Lond.). 227:680685.

15. Maniatis, T., E. F. Fritsch, and J. Sambrook. 1982. Molecular Cloning: A Laboratory Manual. Cold Spring Harbor Laboratory, Cold Spring Harbor, NY. 545 pp.

16. Chinard, F. P. 1952. Photometric estimation of proline and ornithine. J. Biol. Chem. 199:265-275.

17. Endo, F., and I. Matsuda. 1981. Screening method for prolidase deficiency. Hum. Genet. 56:349-351.

18. Sheffield, L. J., P. Schlesinger, K. Faull, B. J. Halpern, G. M. Schier, R. G. H. Cotton, J. Hammond, and D. M. Danks. 1977. Iminopeptiduria, skin ulcerations, and edema in a boy with prolidase deficiency. J. Pediatr. 91:578-583.

19. Sei, Y., Y. Hayakawa, K. Suzuki, and H. Ishizaki. 1988. Prolidase deficiency. Hifu. 30:734-740.

20. Jackson, S. H., A. W. Dennis, and M. Greenberg. 1975. Iminopeptidura. A genetic defect in recycling collagen: a method for determining prolidase in red blood cells. Can. Med. Assoc. J. 113:759-763.

21. Powell, G. F., M. A. Rasco, and R. M. Maniscalco. 1974. A prolidase deficiency in man with iminopeptiduria. Metab. Clin. Exp. 23:505-513.
22. Powell, G. F., A. Kurosky, and R. M. Maniscalco. 1977. Prolidase deficiency: report of a second case with quantitation of the excessively excreted amino acids. J. Pediatr. 91:242-246.

23. Miech, G., I. Myara, M. Mangeot, V. Voigteander, and A. Lemonnier. 1988. Prolidase activity in prolidase deficient fibroblasts. J. Inherited Metab. Dis. 11:266-269.

24. Butterworth, J., and D. Priestman. 1984. Substrate specificity of manganese activated prolidase in control and prolidase-deficient cultured skin fibroblasts. J. Inherited Metab. Dis. 7:32-34.

25. Ohhashi, T., T. Ohno, J. Arata, and H. Kodama. 1988. Biochemical studies on prolidase in sera from control, patients with prolidase deficiency and their mother. J. Inherited Metab. Dis. 11:166-173.

26. Lombeck, I., U. Wendel, J. Versieck, L. Van Ballenberghe, H. J. Bremer, M. Duran, and S. K. Wadman. 1986. Increased manganese content and reduced arginase activity in erythrocytes of a patient with prolidase deficiency (iminodipeptiduria). Eur. J. Pediatr. 144:571-573.

27. Lapière, Ch. M., and B. Nusgens. 1969. Plaies cutanées torpides et trouble du metabolism du collagene. Arch. Belg. Dermatol. 25:353356.

28. Ogata, A., S. Tanaka, T. Tomoda, E. Murayama, F. Endo, and I. Kikuchi. 1981. Autosomal recessive prolidase deficiency: three patients with recalcitrant leg ulcer. Arch. Dermatol. 177:689-694.

29. Endo, F., I. Matsuda, A. Ogata, and S. Tanaka. 1982. Human erythrocyte prolidase and prolidase deficiency. Pediatr. Res. 16:227231.

30. Arata, J., S. Umemura, Y. Yamamoto, M. Hagiyama, and N. Nohara. 1979. Prolidase deficiency, its dermatological manifestations and some additional biochemical studies. Arch. Dermatol. 115:62-68. 